\title{
Levels of major and trace elements in fennel (Foeniculum vulgari Mill.) fruits cultivated in Ethiopia
}

Feleke Demissie Endalamaw ${ }^{1,2}$ and Bhagwan Singh Chandravanshi ${ }^{{ }^{*}}$

\begin{abstract}
Background: Sweet fennel (Foeniculum vulgare Mill.) is one of the precious spices. Almost all parts of fennel plant are edible. The herb is used as carminative, digestive, diuretic, cosmetic and medicine.

Methods: A $0.5 \mathrm{~g}$ of the oven dried fennel fruit and soil samples were digested by wet-digestion method. The levels of selected elements ( $\mathrm{Ca}, \mathrm{Mg}, \mathrm{Fe}, \mathrm{Mn}, \mathrm{Cu}, \mathrm{Cr}, \mathrm{Co}, \mathrm{Zn}, \mathrm{Ni}, \mathrm{Cd}$ and $\mathrm{Pb}$ ) were determined in sweet fennel fruit (Foeniculum vulgari Mill.) and soil from Addis Ababa (Central Ethiopia) and Gojjam (Northern West Ethiopia) by flame atomic absorption spectrometry (FAAS).

Results: The elemental concentrations $(\mu \mathrm{g} / \mathrm{g})$ in fennel fruit were: Ca $(20,500-23,000), \mathrm{Mg}(1,310-3,460)$, Fe (1,140-1,900), Mn (31-51), Cu (24-103), Cr (91-98), Co (26-71), Zn (37-45), Ni (19-24), and Cd (1.6-1.9) while in the soil were: $\mathrm{Ca}(1,440-1,780), \mathrm{Mg}(1,260-3,310)$, Fe $(26,900-28,000), \mathrm{Mn}(1,460-1,980), \mathrm{Cu}(51-101), \mathrm{Cr}$ (127-141), Co (54-143), Zn (99-104), Ni (98-161), and Cd (1.7-2.9). Pb was below the method detection limit in both the fennel fruit and soil.

Conclusion: The Ethiopian fennel fruits are rich in $\mathrm{Ca}$ and $\mathrm{Mg}$ and other essential elements ( $\mathrm{Fe}, \mathrm{Cu}, \mathrm{Co}$ and $\mathrm{Zn}$ ) and can be used as good supplement for human being in particularly for children and pregnant women. The toxic element $\mathrm{Cd}$ is at trace level and $\mathrm{Pb}$ is not detected in the fennel fruit. Thus, Ethiopian fennel fruits are safe for human consumption.
\end{abstract}

Keywords: Fennel; Foeniculum vulgari Mill.; Ensilal; Trace elements; Spice; Ethiopia

\section{Introduction}

Sweet fennel (Foeniculum vulgare Mill.) is one of the precious spices. It is a highly aromatic (Parthasarathy et al. 2008) and flavourful herb with culinary, cosmetic (Rasul et al. 2012; Kim et al. 2004) and medicinal uses (Javidnia et al. 2003; He and Huang 2011; Cetin et al. 2010; Faudale et al. 2008; Mohamad et al. 2011; Qiu et al. 2012; Senatore et al. 2013; Shahat et al. 2011; Dadalioglu and Evrendilek 2004). It has also nutritional values (Renna and Gonnella 2012). It belongs to the family Apiaceae (formerly the Umbelliferae) (Qiu et al. 2012). In Ethiopia, the plant is called Ensilal. It is native to Southern Europe and the Mediterranean region and is cultivated mainly

\footnotetext{
* Correspondence: bscv2006@yahoo.com

${ }^{1}$ Department of Chemistry, College of Natural Sciences, Addis Ababa University, P.O. Box 1176, Addis Ababa, Ethiopia

Full list of author information is available at the end of the article
}

in India, China, Guatemala, Sri Lanka, Greece, and many other countries in Europe and America (Parthasarathy et al. 2008; He and Huang 2011; Rather et al. 2012; Rahimi and Ardekani 2013; Chéry et al. 2008). As to our knowledge, it is cultivated only in Ethiopia in Africa.

Almost all parts of fennel plant are edible. The herb is used as carminative, digestive, and diuretic. It is used in treating respiratory and gastrointestinal disorders (Diao et al. 2014; El-Motaium and El-Seoud 2007). Furthermore, its insect rippling and antimicrobial properties against a wide range of microorganisms have been well established (Qiu et al. 2012; Oktay et al. 2003). Fennel essential oil is used in cosmetics, pharmaceuticals, and perfumery and as a food additive and flavouring agent in food products (Kim et al. 2004; Mohamad et al. 2011; Rather et al. 2012; Oktay et al. 2003). The fennel fruits are used as flavourings in baked goods, meat and fish

\section{空}


dishes, ice cream, alcoholic beverages and herb mixtures. Fennel fruit tea and fennel fruit water are very common traditional medicines for flatulence treatment ( $\mathrm{He}$ and Huang 2011; Rather et al. 2012). In China, fennel fruit is used both as tradition Chinese medicine and as common food with Chinese name Xiaohuixiang (He and Huang 2011).

There are various demands for elemental information in biological and medical samples. Trace elements exhibit significant functions with respect to living organisms in terms of oxygen carrying, electron transfer, enzyme catalyzing, etc. (Singh and Garg 2006; Divrikli et al. 2006; Demirel et al. 2008). For all the elements essential for metabolism, there exists a range of intake over which their supply is adequate for the body beyond which deficiency and toxic effects are observed (Mallinckrodt and Meissne 1994). All the nutrient elements are primarily supplied through diet. However, this may change, depending on age, sex, health status, geographical and climatic conditions (O'Dell and Sunde 1997). Therefore, it is essential to determine elemental contents of food items. WHO and FAO have recommended selective studies of individual foodstuffs as an important step in the estimation of dietary intake of trace elements (FAO/WHO 2001). It is a good practice to include micronutrient density of the diet component in addition to energy and protein adequacy of it (FAO/WHO 2001).

There are some works done on the elemental level of infusion and decoction tea (Desideri et al. 2011; Ozcan et al. 2008; Szymczycha-Madeja et al. 2012; Sembratowicz and Rusinek-prystupa 2014; Başgel and Erdemoğlu 2006; Zengin et al. 2008) of the fennel fruit, steam and leaf. Fennel fruit is eaten cooked or raw in different part of the world. Chewing fennel fruit after a meal is a common practice in India (Shirahatt et al. 2010). Ethiopians use raw or roasted and ground form of it as spice. It is also used to flavor local drinks such as areke and tej. Moreover, in Ethiopia the fennel fruit is used as a spice in the preparation of shiro and berbere and the powdered roasted fennel fruit is added in to traditional dish like doro wot (Getahun 1976; Zuberi et al. 2014). There is no report on the elemental content of fennel fruit in Ethiopia in any form and only few reports (Khattak and Khattak 2011; Chowdhary et al. 2014; Ozcan and Akbulut 2007; Kumar et al. 2005) are available worldwide on the total elemental content of the fennel fruit. None of them correlate the nutrient found in the fennel fruit with the soil it is grown. This study was therefore; designed to assess the levels of major and trace elements $(\mathrm{Ca}, \mathrm{Mg}, \mathrm{Fe}$, $\mathrm{Mn}, \mathrm{Cu}, \mathrm{Cr}, \mathrm{Co}, \mathrm{Zn}, \mathrm{Ni}, \mathrm{Cd}$ and $\mathrm{Pb}$ ) in fennel fruit cultivated in the farmland in Ethiopia. To assess the significance of soil to the growth of fennel, it was also analysed for major and trace elements using flame atomic absorption spectrometry.

\section{Methods}

\section{Instruments and reagents}

Blending device (Moulinex, France), digital analytical balance (Adam, Model WL 3000, Switzerland), hot plate, air-circulating oven (Digitheat, J.P. Selecta, Spain) and flame atomic absorption spectrophotometer (FAAS) (Buck Scientific, Model 210VGP AAS, East Norwalk, USA) were used.

Chemicals and reagents that were used in the analysis were all analytical grades. $69-72 \% \mathrm{HNO}_{3}$ (Supreme Enterprises Cantt, India), $70 \% \mathrm{HClO}_{4}$ (A.C.S. Reagent, Aldrich, UK) and $36 \% \mathrm{H}_{2} \mathrm{O}_{2}$ (Scharlau Chemie, European Union, UN2014) were used for digestion of powdered fennel fruit and soil samples. Lanthanum nitrate hydrate (99.9\%, Aldrich, Muwaukee, USA) was used to prevent the chemical interference of phosphate ion on $\mathrm{Ca}$ and $\mathrm{Mg}$ during the analysis of the samples. Stock standard solution of concentration $1000 \mathrm{mg} / \mathrm{L}$ in $2 \% \mathrm{HNO}_{3}$ of the elements $\mathrm{Ca}, \mathrm{Mg}, \mathrm{Mn}, \mathrm{Fe}, \mathrm{Cu}, \mathrm{Zn}, \mathrm{Ni}, \mathrm{Co}, \mathrm{Cr}, \mathrm{Pb}$ and $\mathrm{Cd}$ (Buck Scientific Puro-Graphic) standard solutions were used to prepare intermediate standard solutions to obtain calibration curves for the determination of elements in the samples and recovery study.

\section{Sampling and sample preparation}

The study locations were Addis Ababa, Bichena, Debre Markos and Finote Selam. Addis Ababa is the capital city of Ethiopia. Bichena and Debre Markos are located in east Gojjam (Ethiopia); they are $299 \mathrm{~km}$ and $265 \mathrm{~km}$ from Addis Ababa, respectively. Finote Selam is found in west Gojjam, which is $380 \mathrm{~km}$ away from the capital city. Addis Ababa was selected because it is expected to be relatively contaminated area and to see the accumulation effect of the plant. Gojjam was selected because fennel is consumed in these zones every day in different ways, as

Table 1 Latitude, longitude, altitude, annual average temperature and annual rain fall of the sites

\begin{tabular}{|c|c|c|c|c|c|}
\hline Name of sites & Latitude (N) & Longitude (E) & Altitude (m) & Annual average temperature $\left({ }^{\circ} \mathrm{C}\right)$ & Annual average rain fall $(\mathrm{mm})$ \\
\hline AA & $8^{\circ} 59^{\prime}$ & $38^{\circ} 48^{\prime}$ & 2,354 & $12-20$ & 1,210 \\
\hline B & $10^{\circ} 27^{\prime}$ & $38^{\circ} 12^{\prime}$ & 2,539 & $9.8-22$ & 1,250 \\
\hline DM & $10^{\circ} 21^{\prime}$ & $37^{\circ} 43^{\prime}$ & 2,440 & $14.2-18.6$ & 1,340 \\
\hline FS & $10^{\circ} 42^{\prime}$ & $37^{\circ} 16^{\prime}$ & 1,905 & $9.8-23.5$ & 1,450 \\
\hline
\end{tabular}

$\mathrm{AA}=$ Addis Ababa, $\mathrm{B}=$ Bichena, $\mathrm{DD}=$ Debre Markos and FS = Finote Selam. 
Table 2 Reagent types and volumes, temperature and time attempted during optimization of digestion of $0.5 \mathrm{~g}$ fennel fruit

\begin{tabular}{|c|c|c|c|c|c|c|}
\hline \multirow[t]{2}{*}{ No. } & \multicolumn{3}{|c|}{ Reagent volume $(\mathrm{mL})$} & \multirow{2}{*}{$\begin{array}{c}\text { Temperature } \\
\left({ }^{\circ} \mathrm{C}\right)\end{array}$} & \multirow{2}{*}{$\begin{array}{l}\text { Time } \\
(\min )\end{array}$} & \multirow[t]{2}{*}{ Results } \\
\hline & $\mathrm{HNO}_{3}$ & $\mathrm{HClO}_{4}$ & Total & & & \\
\hline 1 & 1 & 3 & 4 & 270 & 180 & Yellow \\
\hline 2 & 1.5 & 2.5 & 4 & 270 & 180 & Lightly yellow \\
\hline 3 & 2 & 2 & 4 & 270 & 180 & Almost clear \\
\hline 4 & 2.5 & 1.5 & 4 & 270 & 180 & Clear solution \\
\hline 5 & 3 & 1 & 4 & 270 & 180 & Clear solution \\
\hline 6 & 3.5 & 0.5 & 4 & 270 & 180 & Almost clear \\
\hline 7 & 2.5 & 1.5 & 4 & 120 & 180 & Yellow \\
\hline 8 & 2.5 & 1.5 & 4 & 150 & 180 & Lightly yellow \\
\hline 9 & 2.5 & 1.5 & 4 & 180 & 180 & Almost clear \\
\hline 10 & 2.5 & 1.5 & 4 & 210 & 180 & Clear solution \\
\hline 11 & 2.5 & 1.5 & 4 & 240 & 180 & Clear solution \\
\hline 12 & 2.5 & 1.5 & 4 & 270 & 180 & Clear solution \\
\hline 13 & 2.5 & 1.5 & 4 & 270 & 105 & Light brown with suspension \\
\hline 14 & 2.5 & 1.5 & 4 & 270 & 120 & Yellow \\
\hline 15 & 2.5 & 1.5 & 4 & 270 & 135 & Lightly yellow \\
\hline 16 & 2.5 & 1.5 & 4 & 270 & 150 & Clear solution \\
\hline 17 & 2.5 & 1.5 & 4 & 270 & 165 & Clear solution \\
\hline 18 & 2.5 & 1.5 & 4 & 270 & 180 & Clear solution \\
\hline
\end{tabular}

Rows with bold font indicate the optimal condition for the given parameter.

spice, flavouring agent in local areki and used as medicinal plant. Latitude, longitude, altitude, annual average temperature and rainfall of the sampling sites of fennel fruit are given in Table 1.

Fennel fruit samples were collected during the dry season (March - April 2010). A total of 5 sub-sites were selected for each site and $100 \mathrm{~g}$ fennel fruit and $100 \mathrm{~g}$ soil were collected from each sub-site. The sub-sites were selected randomly. The samples collected in each sub-sites were pooled and $0.5 \mathrm{~kg}$ of bulk sample were collected for each of the sites. The soil samples were collected at a depth of $20 \mathrm{~cm}$ from the surface of the top soil. Samples were sealed in polyethylene bags and transported to the laboratory. All the samples were dried in the oven at $70^{\circ} \mathrm{C}$ for 48 hours for fennel fruit and 72 hours for soil until the mass of the samples became constant.

\section{Optimization of digestion procedure}

In this study nitric and perchloric acids were used during optimization procedure for fennel fruit and a total

Table 3 Reagent types and volumes, temperature and time attempted during optimization of digestion of $0.5 \mathrm{~g}$ soil

\begin{tabular}{|c|c|c|c|c|c|c|}
\hline \multirow[t]{2}{*}{ No. } & \multicolumn{3}{|c|}{ Reagent volume (mL) } & \multirow{2}{*}{$\begin{array}{c}\text { Temperature } \\
\left({ }^{\circ} \mathrm{C}\right)\end{array}$} & \multirow{2}{*}{$\begin{array}{l}\text { Time } \\
(\min )\end{array}$} & \multirow[t]{2}{*}{ Results } \\
\hline & $\mathrm{HNO}_{3}$ & $\mathrm{HClO}_{4}$ & $\mathrm{H}_{2} \mathrm{O}_{2}$ & & & \\
\hline 1 & 2.2 & 4.4 & 1 & 300 & 180 & Deep yellow with suspension \\
\hline 2 & 2 & 4 & 1.5 & 300 & 180 & Light yellow with no suspension \\
\hline 3 & 1.8 & 3.6 & 2 & 300 & 180 & Light yellow with no suspension \\
\hline 4 & 2 & 4 & 1.5 & 240 & 180 & Deep yellow with suspension \\
\hline 5 & 2 & 4 & 1.5 & 270 & 180 & Light yellow with no suspension \\
\hline 6 & 2 & 4 & 1.5 & 300 & 180 & Light yellow with no suspension \\
\hline 7 & 2 & 4 & 1.5 & 270 & 120 & Deep Yellow with suspension \\
\hline 8 & 2 & 4 & 1.5 & 270 & 150 & Light yellow with suspension \\
\hline 9 & 2 & 4 & 1.5 & 270 & 180 & Light yellow with no suspension \\
\hline
\end{tabular}

Rows with bold font indicate the optimal condition for the given parameter. 
Table 4 Method detection limits for elements (for all metals, $n=6$ )

\begin{tabular}{|c|c|c|c|c|c|c|c|c|c|c|c|}
\hline Element & $\mathrm{Ca}$ & $\mathrm{Mg}$ & $M n$ & $\mathrm{Fe}$ & $\mathrm{Zn}$ & $\mathrm{Cu}$ & $\mathrm{Cr}$ & Co & $\mathrm{Ni}$ & $\mathrm{Cd}$ & $\mathrm{Pb}$ \\
\hline $\begin{array}{l}\text { MDL for fennel } \\
\text { fruit }(\mu \mathrm{g} / \mathrm{g})\end{array}$ & 3 & 0.4 & 0.5 & 0.2 & 0.6 & 0.5 & 3 & 4 & 1 & 0.1 & 5 \\
\hline MDL for soil $(\mu \mathrm{g} / \mathrm{g})$ & 5 & 0.5 & 1.5 & 0.4 & 2 & 2 & 3 & 3 & 3 & 1 & 5 \\
\hline
\end{tabular}

$\mathrm{MDL}=$ Method detection limit.

volume of acid was taken to be $4 \mathrm{~mL}$. The ratio of the acids, temperature and time of digestion were optimized. The results are given in Table 2 . Therefore, the procedure with total of $4 \mathrm{~mL}$ reagents volume $\left(2.5 \mathrm{~mL} \mathrm{HNO}_{3}\right.$ and $1.5 \mathrm{~mL} \mathrm{HClO}_{4}$ ), heating at $210^{\circ} \mathrm{C}$ and 150 min digestion time was selected for this study. Similar optimization also carried out for the soil sample digestion using $\mathrm{HNO}_{3}$, $\mathrm{HClO}_{4}$ and $\mathrm{H}_{2} \mathrm{O}_{2}$. The results are given in Table 3. The optimum condition obtained was $2 \mathrm{~mL} \mathrm{HNO}_{3}(69-72 \%)$, $4 \mathrm{~mL} \mathrm{HClO}_{4}(70 \%)$ and $1.5 \mathrm{~mL}$ of $\mathrm{H}_{2} \mathrm{O}_{2}(36 \%)$ and at temperature $270^{\circ} \mathrm{C}$ for $180 \mathrm{~min}$. The solid dry sample (for both soil and fennel fruit) digested by this procedure was $0.5 \mathrm{~g}$.

Fennel fruit samples were digested by applying the optimized procedure. A $0.5 \mathrm{~g}$ of well-powdered fennel fruit sample was added into a round bottom flask $(100 \mathrm{~mL})$. To this flask $2.5 \mathrm{~mL} \mathrm{HNO}_{3}(69-72 \%)$ and $1.5 \mathrm{~mL} \mathrm{HClO}_{4}$ (70\%) were added and the mixtures were digested on a micro Kjeldahl digestion apparatus by setting the temperature at $210^{\circ} \mathrm{C}$ for $150 \mathrm{~min}$.

Soil samples were digested by applying the optimized procedure. A $0.5 \mathrm{~g}$ of well-powdered soil sample was added into a round bottom flask $(100 \mathrm{~mL})$. To this flask $2 \mathrm{~mL}$ $\mathrm{HNO}_{3}(69-72 \%), 4 \mathrm{~mL} \mathrm{HClO}_{4}$ (70\%) and $1.5 \mathrm{~mL}$ of $\mathrm{H}_{2} \mathrm{O}_{2}$ (36\%) were added and the mixtures were digested on a micro Kjeldahl digestion apparatus by setting the temperature at $270^{\circ} \mathrm{C}$ for $180 \mathrm{~min}$.

After cooling of the digest, about $15 \mathrm{~mL}$ of de-ionized water was added to dissolve the precipitates formed on cooling and to dilute left over acid so that to minimize the dissolution of a filter paper by the digest residue while filtrating with Whatman, $(110 \mathrm{~mm}$, dia), filter paper. The round bottom flask was rinsed by using $8 \mathrm{~mL}$ de-ionized water two times and filtered. The filtrate was filled to $50 \mathrm{~mL}$ with de-ionized water. Triplicate digestions were carried out for each sample of soil and fennel fruit. Six blank solutions were prepared by digesting the mixture of reagents following the same procedure. The digested samples were kept in the refrigerator, until the level of all the elements in the sample solutions were determined by FAAS.

\section{Instrument calibration}

Six points calibration curve were established by running series of the prepared working standard solutions. Correlation coefficients obtained for calibration curve were $>0.999$. Immediately after calibration, the sample solutions were aspirated into the FAAS instrument and direct readings of the elemental concentrations was recorded. Calibration of the instrument was checked periodically during operation. Three replicate determinations were carried out on each sample. Blank analysis was also done similarly.

\section{Method validation}

The method detection limit of each element was calculated as tree times the standard deviation of the blank $\left(3 \sigma_{\text {blank }}, n=6\right)$. The method detection limit for fennel fruit and soil samples are presented in Table 4. The method detection limits are low enough which clearly indicate that the selected elements can be detected at trace level by the FAAS method used.

To check the accuracy of digestion procedure and efficiency of the FAAS instrument spiked samples were prepared by adding a small known quantity of elemental standard solutions to both the soil and fennel fruit by applying similar digestion procedure, analysing for the levels of elements and calculating the recovery percent. The obtained percentage recovery for the fennel fruit varied from $93 \%$ to $108 \%$ and for the soil from $93 \%$ to $110 \%$ which are in the acceptable range. The reproducibility of the analytical procedure was checked by carrying out a triplicate analysis and calculating the coefficient of variation of the mean for each metal. In almost all cases, triplicate results did not differ by more than $10 \%$ of the mean.

Table 5 Average concentration of elements ( $\mu \mathrm{g} / \mathrm{g}$ dry weight) in the fennel fruit samples from the four sites (mean \pm SD, $n=3$ )

\begin{tabular}{|c|c|c|c|c|c|c|c|c|c|c|c|}
\hline Element & $\mathrm{Ca}$ & $\mathrm{Mg}$ & $\mathrm{Fe}$ & $M n$ & $\mathrm{Cu}$ & $\mathrm{Cr}$ & Co & $\mathrm{Zn}$ & $\mathrm{Ni}$ & $\mathrm{Cd}$ & $\mathrm{Pb}$ \\
\hline$\overline{A A}$ & $00 \pm 290$ & $90 \pm 68$ & $0 \pm 67$ & \pm 1.1 & \pm 4 & $7 \pm 2.9$ & $67.7 \pm 3.7$ & $37.1 \pm 2.0$ & $18.7 \pm 0.5$ & $1.90 \pm 0.10$ & ND \\
\hline B & $23,000 \pm 240$ & $1,970 \pm 83$ & $1,900 \pm 81$ & $51.4 \pm 1.3$ & $48.4 \pm 0.6$ & $91.4 \pm 2.4$ & $26.2 \pm 0.3$ & $37.8 \pm 2.2$ & $24.2 \pm 1.1$ & $1.67 \pm 0.10$ & \\
\hline DD &, $400 \pm$ & $3,460 \pm 93$ & $1,480 \pm 62$ & 48.1 & 62.5 & 94.0 & 49.5 & 2.5 & $=0.7$ & $=0.08$ & \\
\hline$c$ & $22,900 \pm 570$ & $1,310 \pm 58$ & $1,470 \pm 74$ & $30.6 \pm 0.7$ & $23.9 \pm 0.2$ & $90.9 \pm 0.4$ & $70.8 \pm 0.6$ & $40.8 \pm 1.3$ & $24.2 \pm 0.6$ & $1.59 \pm 0.10$ & \\
\hline
\end{tabular}

$\mathrm{AA}=$ Addis Ababa, $\mathrm{B}=$ Bichena, $\mathrm{DD}=$ Debre Markos, $\mathrm{FS}=$ Finote Selam and ND = not detected. 
Table 6 Average concentration of elements ( $\mu \mathrm{g} / \mathrm{g}$ dry weight) in the soil of the four sites $(\mathrm{mean} \pm \mathrm{SD}, \mathrm{n}=3$ )

\begin{tabular}{|c|c|c|c|c|c|c|c|c|c|c|c|}
\hline Element & $\mathrm{Ca}$ & $\mathrm{Mg}$ & $\mathrm{Fe}$ & $M n$ & $\mathrm{Cu}$ & $\mathrm{Cr}$ & Co & $\mathrm{Zn}$ & $\mathrm{Ni}$ & $\mathrm{Cd}$ & $\mathrm{Pb}$ \\
\hline$A$ & $440 \pm 37$ & $2,870 \pm 59$ & $27,600 \pm 570$ & $1,930 \pm 30$ & $101 \pm 6$ & $1 \pm 5$ & $143 \pm 4$ & $101 \pm 3$ & $98 \pm 4$ & $2.10 \pm 0.10$ & $\mathrm{ND}$ \\
\hline B & $1,780 \pm 37$ & $2,260 \pm 22$ & $27,200 \pm 180$ & $1,980 \pm 15$ & $51.0 \pm 0.5$ & $127 \pm 6$ & $54.3 \pm 0.7$ & $99.0 \pm 2$ & $100 \pm 1$ & $2.90 \pm 0.03$ & ND \\
\hline DD & $1,630 \pm 76$ & $3,310 \pm 94$ & $26,900 \pm 170$ & $1,980 \pm 23$ & $67.9 \pm 2.1$ & $129 \pm 6$ & $115 \pm 1$ & $104 \pm 4$ & $130 \pm 2$ & $2.41 \pm 0.20$ & $\mathrm{NL}$ \\
\hline FS & $1,770 \pm 41$ & $1,260 \pm 50$ & $28,000 \pm 75$ & $1,460 \pm 36$ & $69.6 \pm 0.6$ & $129 \pm 6$ & $133 \pm 7$ & $103 \pm 2$ & $161 \pm 1$ & $1.66 \pm 0.10$ & ND \\
\hline
\end{tabular}

$\mathrm{AA}=$ Addis Ababa, $\mathrm{B}=$ Bichena, $\mathrm{DD}=$ Debre Markos, $\mathrm{FS}=$ Finote Selam and $\mathrm{ND}=$ not detected.

\section{Statistical analysis}

The multivariate analysis of variance for the equality of means and correlation between the elements in fennel fruit and soil samples were done using the SPSS 16.0.

\section{Results}

The fennel fruit and the soil samples on which the plant was grown were analyzed for major $(\mathrm{Ca}, \mathrm{Mg}, \mathrm{Fe}$, and $\mathrm{Mn})$, trace essential ( $\mathrm{Cu}, \mathrm{Zn}, \mathrm{Cr}$ and $\mathrm{Co})$, and trace nonessential elements $(\mathrm{Ni}, \mathrm{Cd}$ and $\mathrm{Pb}$ ) with FAAS. The mean concentrations along with standard deviation of triplicate analysis are given from Tables 5 and 6 for the fennel fruit and soil samples, respectively.

Ten elements ( $\mathrm{Ca}, \mathrm{Mg}, \mathrm{Fe}, \mathrm{Mn}, \mathrm{Cu}, \mathrm{Cr}, \mathrm{Co}, \mathrm{Zn}, \mathrm{Ni}$, and $\mathrm{Cd}$ ) were detected in both the fennel fruit and soil samples while $\mathrm{Pb}$ was not detected in both the fennel fruit and soil samples. The levels of elements however differ significantly among each other and to some extent between sampling sites. The variation between the sampling sites is due to variation in geological, geographical and climatic conditions of the sites. The trend of variation in fennel fruit sample in Addis Ababa site is $\mathrm{Ca}>$ $\mathrm{Mg}>\mathrm{Fe}>\mathrm{Cu}>\mathrm{Cr}>\mathrm{Co}>\mathrm{Mn}>\mathrm{Zn}>\mathrm{Ni}>\mathrm{Cd}$, in Bichena site is $\mathrm{Ca}>\mathrm{Mg}>\mathrm{Fe}>\mathrm{Cr}>\mathrm{Mn}>\mathrm{Cu}>\mathrm{Zn}>\mathrm{Co}>\mathrm{Ni}>\mathrm{Cd}$, in Debre Markos site is $\mathrm{Ca}>\mathrm{Mg}>\mathrm{Fe}>\mathrm{Cr}>\mathrm{Cu}>\mathrm{Co}>$ $\mathrm{Mn}>\mathrm{Zn}>\mathrm{Ni}>\mathrm{Cd}$ and in Finote Selam site is $\mathrm{Ca}>\mathrm{Fe}>$ $\mathrm{Mg}>\mathrm{Cr}>\mathrm{Co}>\mathrm{Zn}>\mathrm{Mn}>\mathrm{Ni}>\mathrm{Cu}>\mathrm{Cd}$. The trend of variation in soil sample in Addis Ababa site is $\mathrm{Fe}>\mathrm{Mg}>\mathrm{Mn}>$ $\mathrm{Ca}>\mathrm{Co}>\mathrm{Cr}>\mathrm{Cu}=\mathrm{Zn}>\mathrm{Ni}>\mathrm{Cd}$, in Bichena site is $\mathrm{Fe}>$ $\mathrm{Mg}>\mathrm{Mn}>\mathrm{Ca}>\mathrm{Cr}>\mathrm{Ni}>\mathrm{Zn}>\mathrm{Co}>\mathrm{Cu}>\mathrm{Cd}$, in Debre Markos site is $\mathrm{Fe}>\mathrm{Mg}>\mathrm{Mn}>\mathrm{Ca}>\mathrm{Ni}>\mathrm{Cr}>\mathrm{Co}>\mathrm{Zn}>$ $\mathrm{Cu}>\mathrm{Cd}$ and in Finote Selam site is $\mathrm{Fe}>\mathrm{Ca}>\mathrm{Mn}>\mathrm{Mg}>$ $\mathrm{Ni}>\mathrm{Co}>\mathrm{Cr}>\mathrm{Zn}>\mathrm{Cu}>\mathrm{Cd}$. In all the cases concentration of $\mathrm{Ca}$ and $\mathrm{Fe}$ are much higher than the other elements in the both the fennel fruit and soil, respectively. In both the fennel fruit and the soil the level of $\mathrm{Cd}$ is much low at trace level but its concentration in the soil is relatively higher than the fennel fruit.

Table 5 indicates that except $\mathrm{Cd}$ which has lowest concentration in samples from Finote Selam and $\mathrm{Ni}$ in samples from Addis Ababa all the other essential trace elements lowest concentrations were found in samples from Bichena. All the trace elements have higher concentrations in samples from Addis Ababa $(\mathrm{Cu}, \mathrm{Cr}, \mathrm{Co}$ and $\mathrm{Cd}$ ) except $\mathrm{Zn}$ in samples from Debre Markos and $\mathrm{Ni}$ in samples from Finote Selam. These go with the expectation of minor pollution in the capital city, Addis Ababa. Table 6 indicates that $\mathrm{Co}$ and $\mathrm{Cr}$ was the most accumulated trace element in the soil sample while the level of $\mathrm{Cd}$ was the lowest among the elements. Since Ethiopia is $10^{\text {th }}$ in the world and $1^{\text {st }}$ in Africa in cattle, leather industries are flourishing in the country. Relatively larger accumulation of $\mathrm{Cr}$ in the soil may be due to release of $\mathrm{Cr}$ in the nearby leather industries but the source of Co is unknown.

\section{Discussion}

Elements are persistent in the environment and tend to bioaccumulate in plants and organisms. Bioaccumulation is of course a normal and essential process enabling the organism to have reserve for latter use for metalloproteins or cofactors or protect themselves against toxic effects (Kitata and Chandravanshi 2012). In this study the bioaccumulation of both trace and major elements were attempted to be verified by roughly comparing their concentration in one of the growth media, soil and those in plants.

In comparison between soil and fennel fruit sample except for $\mathrm{Ca}$ fennel fruit showed less or comparable accumulation of elements found in the soil. Higher accumulation was observed for $\mathrm{Ca}$ only (Table 7 and Figure 1A). This may be because it is a seasonal plant and the soil is acidic. Ca accumulation ability of fennel

Table 7 Accumulation coefficient of elements from the soil to fennel fruit

\begin{tabular}{lcccc}
\hline Element & \multicolumn{4}{c}{ Sampling sites } \\
\cline { 2 - 5 } & AA & B & DM & FS \\
\hline Ca & 14.2 & 12.9 & 13.1 & 12.9 \\
$\mathbf{M g}$ & 0.72 & 0.87 & 1.2 & 0.96 \\
$\mathbf{M n}$ & 0.021 & 0.015 & 0.056 & 0.035 \\
$\mathbf{F e}$ & 0.041 & 0.070 & 0.055 & 0.052 \\
$\mathbf{Z n}$ & 0.35 & 0.38 & 0.43 & 0.40 \\
$\mathbf{C u}$ & 1.0 & 1.4 & 0.35 & 0.26 \\
$\mathbf{C r}$ & 0.67 & 0.46 & 0.76 & 0.40 \\
$\mathbf{C o}$ & 0.49 & 0.19 & 0.11 & 0.54 \\
$\mathbf{N i}$ & 0.25 & 0.19 & 0.19 & 0.15 \\
$\mathbf{C d}$ & 0.91 & 0.58 & 0.78 & 0.96 \\
\hline AA & &
\end{tabular}

$\mathrm{AA}=$ Addis Ababa, $\mathrm{B}=$ Bichena, $\mathrm{DD}=$ Debre Markos and FS = Finote Selam. 

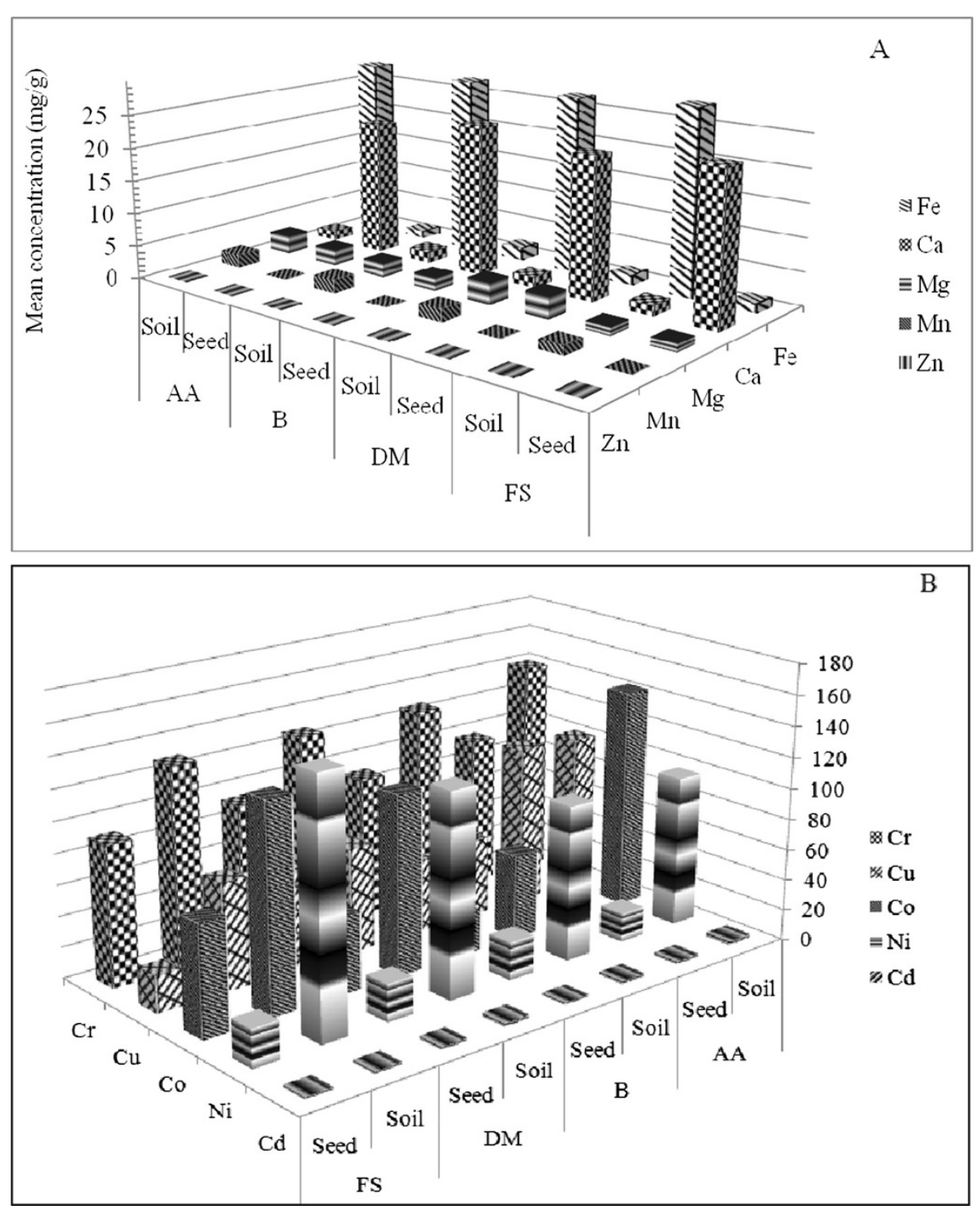

Figure 1 Comparison of concentration of elements in the fennel fruit to elements in the soil. A. Major elements and $\mathbf{B}$. trace elements. $\mathrm{AA}=$ Addis Ababa, $\mathrm{B}=$ Bichena, $\mathrm{DD}=$ Debre Markos and FS = Finote Selam.

fruit makes it valuable Ca resource for infants, pregnant women and elderly persons who need it very much in addition to its medicinal and spicy nature. However, it is not possible to estimate the daily intake of $\mathrm{Ca}$ from fennel fruit by infant, pregnant women and elderly persons living in different parts of the country due to their variable daily intake. Also there is no systematic data available on the daily intake of fennel fruit. For $\mathrm{Mg}$ and $\mathrm{Cu}$ fennel fruit showed comparable accumulation to that of the soil but for $\mathrm{Fe}, \mathrm{Mn}, \mathrm{Cr}, \mathrm{Co}, \mathrm{Zn}, \mathrm{Ni}$ and $\mathrm{Cd}$ it showed low accumulation than available in the soil in all the sites. This might indicates that they are not found in bio-available form or fennel fruit has poor accumulation for these elements. The very low concentration of $\mathrm{Cd}$ and not detectable $\mathrm{Pb}$
Table 8 FAO/WHO dietary recommendation of some of the minerals (mg/day)

\begin{tabular}{lllll}
\hline Metals & \multicolumn{4}{c}{ Population groups } \\
\cline { 2 - 5 } & Infants & $\begin{array}{l}\text { Pregnant } \\
\text { women }\end{array}$ & $\begin{array}{l}\text { Lactating } \\
\text { women }\end{array}$ & $\begin{array}{l}\text { Elderly } \\
\text { (>65 year) }\end{array}$ \\
\hline $\mathbf{C a}$ & $300-400$ & 1200 & 1000 & 1300 \\
$\mathbf{M g}$ & $26-36$ & 220 & 270 & $190-230$ \\
$\mathbf{Z n}$ & $2.8-4.1$ & $5.5-10$ & $7.2-9.5$ & $4.9-7.0$ \\
$\mathbf{F e}$ & $8-9$ & 1040 & 15 & $11-14$ \\
\hline
\end{tabular}

N.B. WHO recommendation for toxic metals in herbal medicines and products are: $10 \mathrm{mg} / \mathrm{kg}$ and $0.3 \mathrm{mg} / \mathrm{kg}$ for $\mathrm{Pb}$ and $\mathrm{Cd}$, respectively. 
Table 9 Summary of elemental levels reported fennel fruit worldwide (all values are in $\mu \mathrm{g} / \mathrm{g}$ )

\begin{tabular}{lccccc}
\hline Country & Ca & Mg & Fe & Mn & Ref. \\
\hline India & $23,900 \pm 1300$ & $5,110 \pm 420$ & $744 \pm 20$ & $72.3 \pm 3.0$ & (Kumar et al. 2005) \\
Turkey & $10,800 \pm 220$ & $2,770 \pm 39$ & $225 \pm 9$ & $27.8 \pm 0.4$ & (Başgel \& Erdemoğlu 2006) \\
Turkey & $6,750 \pm 120$ & $3,400 \pm 380$ & $316 \pm 35$ & $33.4 \pm 5.3$ & (Ozcan and Akbulut 2007) \\
Pakistan & - & - & $1030 \pm 290$ & $877 \pm 85$ & (Khattak and Khattak 2011) \\
Ethiopia & $21,900 \pm 1,190$ & $2,280 \pm 900$ & $1,500 \pm 310$ & $44.0 \pm 9.2$ & Present study \\
\hline
\end{tabular}

in the fennel fruit indicate that the risk of toxicity of these elements is low when consuming it in row or processed forms. The FAO/WHO dietary recommendations of some of the metals are given in Table 8 .

The accumulation factor of the fennel fruit is evaluated and the result is presented in Table 7. Ca has highest accumulation coefficient (12.9-14.2) in all the sites. The reason for higher concentration of $\mathrm{Ca}$ in the fennel fruit is due to the acidity of the soil as a result of higher concentration of Fe $(28,000-26,900 \mu \mathrm{g} / \mathrm{g})$. The least accumulation is seen for Mn (0.015-0.056) in all the sites. Elements like $\mathrm{Mg}, \mathrm{Cu}$ and $\mathrm{Cd}$ have variable concentration in the plant as that in the soil. For Cr, moderate difference in concentration is observed. In the case of $\mathrm{Zn}$ and Co, the concentration in the soil is higher than the fennel fruit at roughly by half. For other elements like $\mathrm{Fe}, \mathrm{Mn}$ and $\mathrm{Ni}$ the concentration of the soil is very high (Figure $1 \mathrm{~A}$ and $\mathrm{B}$ ).

\section{Comparison of levels of elemental in fennel fruit with literature values}

The major elements ( $\mathrm{Ca}, \mathrm{Mg}, \mathrm{Fe}$ and $\mathrm{Mn}$ ) have been determined in the fennel fruit in different countries from different points of view (nutritional, health problems, crop yield, etc.). Some of the available studies are presented in Table 9 along with the present study for comparison.

The level of $\mathrm{Ca}$, in this study is comparable with the study from India (Kumar et al. 2005) but much higher than from Turkey (Başgel and Erdemoğlu 2006; Ozcan and Akbulut 2007). The level of $\mathrm{Mg}$ in this study is lower than from Turkey (Başgel and Erdemoğlu 2006; Ozcan and Akbulut 2007), and much lower than study from India (Kumar et al. 2005). The level of Fe in this study is much higher than studies from India and Turkey
(Başgel \& Erdemoğlu 2006; Ozcan and Akbulut 2007; Kumar et al. 2005). The level of Mn in this study is lower than study from India but higher than Turkey (Başgel and Erdemoğlu 2006; Ozcan and Akbulut 2007; Kumar et al. 2005). Generally the values are acceptable except Fe which is very high than the literature values.

Comparisons of levels of trace elements in fennel fruit reported in various parts of the world are summarized in Table 10. Results for $\mathrm{Cu}, \mathrm{Cr}$, and $\mathrm{Co}$ of this study are much higher than the literature values given in Table 10. This variation may be due to difference in the geographical location, climate, agricultural chemicals like fertilizers or errors in sample preparation and analysis. Extremely higher values for $\mathrm{Cr}$ may be related to pollution from the tannery industry found around the sampling areas. Results of this study for $\mathrm{Zn}, \mathrm{Ni}$ and $\mathrm{Cd}$ are comparable with literature values.

\section{Multivariate analysis of variance}

Variation in the mean levels of elements between the fennel fruit and soil samples were tested based on Tukey HSD multiple comparison model. $\mathrm{Mg}$ and $\mathrm{Cd}$ show significant differences $(\mathrm{p}<0.05)$ at $95 \%$ confidence levels for all sampling sites whereas $\mathrm{Zn}$ in all sites and Fe except Addis Ababa and Debre Markos sites showed significant similarity $(p>0.05)$. These may indicate that fennel fruit has special storing capability for $\mathrm{Mg}$ and $\mathrm{Cd}$ irrespective of their concentration in the soil whereas Fe and $\mathrm{Zn}$ accumulation is the reflection of their concentration in the soil. Other elements show partial significant similarity and difference.

$\mathrm{Ca}$ (only in Bichena and Finote Selam), Cu (only in Finote Selam and Debre Markos), Co (only in Addis Ababa and Finote Selam) and Ni (only in Addis Ababa and Bichena)

Table 10 Summary of trace elemental levels in fennel fruit worldwide (all values in $\mu \mathrm{g} / \mathrm{g}$ )

\begin{tabular}{|c|c|c|c|c|c|c|c|}
\hline Country & $\mathrm{Cu}$ & $\mathrm{Cr}$ & Co & $\mathrm{Zn}$ & $\mathrm{Ni}$ & Cd & Ref. \\
\hline India & $10.9 \pm 0.8$ & $1.50 \pm 0.35$ & $0.54 \pm 0.10$ & $34.5 \pm 4.4$ & $1.46 \pm 3.43$ & $0.086 \pm 0.034$ & (Kumar et al. 2005) \\
\hline Turkey & $16.2 \pm 0.4$ & $1.04 \pm 0.20$ & $0.40 \pm 0.02$ & $37.0 \pm 2.4$ & $5.40 \pm 0.14$ & $0.004 \pm 0.001$ & (Başgel \& Erdemoğlu 2006) \\
\hline Turkey & $8.28 \pm 0.85$ & $35.9 \pm 9.12$ & - & $20.8 \pm 4.78$ & $28.7 \pm 1.38$ & $0.50 \pm 0.1$ & (Ozcan and Akbulut 2007) \\
\hline Pakistan & $117 \pm 22$ & - & - & $37.5 \pm 3.0$ & - & - & (Khattak and Khattak 2011) \\
\hline Pakistan & & & & $24.7 \pm 0.5$ & & & (Chowdhary et al. 2014) \\
\hline Ethiopia & $59.5 \pm 33.1$ & $93.5 \pm 3.1$ & $53.5 \pm 20.5$ & $40.1 \pm 3.5$ & $22.8 \pm 2.7$ & $1.54 \pm 0.16$ & Present study \\
\hline
\end{tabular}


Table 11 Single tailed Pearson Correlation of elements in the fennel fruit $(\mathbf{N}=12)$

\begin{tabular}{|c|c|c|c|c|c|c|c|c|c|c|}
\hline Elements & $\mathrm{Ca}$ & $\mathrm{Mg}$ & $\mathrm{Mn}$ & $\mathrm{Fe}$ & $\mathrm{Zn}$ & $\mathrm{Cu}$ & $\mathrm{Cr}$ & Co & $\mathrm{Ni}$ & $\mathrm{Cd}$ \\
\hline$\overline{\mathrm{Ca}}$ & 1.000 & $0.553^{\boldsymbol{\Lambda}}$ & -0.268 & $0.402^{\bullet}$ & $0.232^{\bullet}$ & $0.588^{\mathbf{\Lambda}}$ & -0.964 & $0.192^{\bullet}$ & $0.118^{\bullet}$ & $0.240^{\circ}$ \\
\hline $\mathrm{Mg}$ & 0.553 & 1.000 & -0.605 & -0.313 & $0.768^{\wedge}$ & -0.047 & -0.427 & -0.652 & -0.152 & -0.521 \\
\hline $\mathrm{Mn}$ & -0.268 & -0.605 & 1.000 & $0.759^{\wedge}$ & -0.173 & $0.442^{\bullet}$ & $0.005^{\bullet}$ & $0.345^{\bullet}$ & -0.587 & $0.185^{\bullet}$ \\
\hline $\mathrm{Fe}$ & 0.402 & -0.313 & 0.759 & 1.000 & -0.154 & $0.820^{\wedge}$ & -0.617 & $0.585^{\wedge}$ & -0.352 & $0.467^{\bullet}$ \\
\hline $\mathrm{Zn}$ & 0.232 & 0.768 & -0.173 & -0.154 & 1.000 & -0.048 & -0.224 & -0.825 & -0.663 & -0.801 \\
\hline $\mathrm{Cu}$ & 0.588 & -0.047 & 0.442 & 0.820 & -0.048 & 1.000 & -0.735 & $0.410^{\bullet}$ & -0.280 & $0.312^{\bullet}$ \\
\hline $\mathrm{Cr}$ & -0.964 & -0.427 & 0.005 & -0.617 & -0.224 & -0.735 & 1.000 & -0.266 & $0.064^{\bullet}$ & -0.265 \\
\hline Co & 0.192 & -0.652 & 0.345 & 0.585 & -0.825 & 0.410 & -0.266 & 1.000 & $0.490^{\bullet}$ & $0.941^{\wedge}$ \\
\hline $\mathrm{Ni}$ & 0.118 & -0.152 & -0.587 & -0.352 & -0.663 & -0.280 & 0.064 & 0.490 & 1.000 & $0.604^{\boldsymbol{\Lambda}}$ \\
\hline $\mathrm{Cd}$ & 0.240 & -0.521 & 0.185 & 0.467 & -0.801 & 0.312 & -0.265 & 0.941 & 0.604 & 1.0 \\
\hline
\end{tabular}

$\mathrm{AA}=$ Addis Ababa, $\mathrm{B}=$ Bichena, $\mathrm{DD}=$ Debre Markos, $\mathrm{FS}=$ Finote Selam.

Bold font indicates poor negative relation $(r>-0.500)$.

The ${ }^{\bullet}$ indicate poor positive relation $(r<0.500)$.

The $\boldsymbol{\Delta}$ indicate strong positive relation $(r>0.500)$.

fennel fruit and soil showed significant similarity whereas for the other they showed significant difference. On the other hand, $\mathrm{Mn}$ and $\mathrm{Cr}$ showed half-half significant similarity and difference.

\section{Pearson correlation of elements}

The high association between elements, evidenced by high positive correlation coefficient, can arise from common anthropogenic or natural sources as well as from similarity in chemical properties. The Pearson correlation matrices using correlation coefficient $(r)$ for the fennel fruit samples of the four sits are shown in Table 11. There is poor negative relation between $\mathrm{Ca}$ and $\mathrm{Mn}, \mathrm{Mg}$ and $\mathrm{Fe}$, $\mathrm{Mg}$ and $\mathrm{Cu}, \mathrm{Mg}$ and $\mathrm{Cr}, \mathrm{Mg}$ and $\mathrm{Ni}, \mathrm{Mg}$ and $\mathrm{Cd}, \mathrm{Mn}$ and $\mathrm{Zn}, \mathrm{Fe}$ and $\mathrm{Zn}, \mathrm{Fe}$ and $\mathrm{Ni}, \mathrm{Zn}$ and $\mathrm{Cu}, \mathrm{Zn}$ and $\mathrm{Cr}, \mathrm{Cu}$ and $\mathrm{Ni}, \mathrm{Cr}$ and $\mathrm{Co}$ and $\mathrm{Cr}$ and $\mathrm{Cd}$. Poor positive correlation was found between $\mathrm{Ca}$ and $\mathrm{Fe}, \mathrm{Zn}, \mathrm{Co}, \mathrm{Ni}$, and $\mathrm{Cd}$; $\mathrm{Mn}$ and $\mathrm{Cu}, \mathrm{Cr}, \mathrm{Co}$ and $\mathrm{Cd}$; $\mathrm{Fe}$ and $\mathrm{Cd} ; \mathrm{Cu}$ and $\mathrm{Co}$ and $\mathrm{Cd}$; and $\mathrm{Ni}$ and $\mathrm{Cr}$ and $\mathrm{Co}$. $\mathrm{Mg}$ has no poor positive relationship with any of the elements. Strong negative relation was seen between $\mathrm{Ca}$ and $\mathrm{Cr}$; $\mathrm{Mg}$ and $\mathrm{Mn}$ and $\mathrm{Co}$; $\mathrm{Mn}$ and $\mathrm{Ni}$; $\mathrm{Fe}$ and $\mathrm{Cr} ; \mathrm{Zn}$ and $\mathrm{Co}, \mathrm{Ni}$ and $\mathrm{Cd}$; and $\mathrm{Cu}$ and $\mathrm{Cr}$. Strong positive relationship found between $\mathrm{Ca}$ and $\mathrm{Mg}$ and $\mathrm{Cu} ; \mathrm{Mg}$ and $\mathrm{Zn} ; \mathrm{Mn}$ and $\mathrm{Fe} ; \mathrm{Fe}$ and $\mathrm{Cu}$ and $\mathrm{Co}$; and $\mathrm{Cd}$ and $\mathrm{Co}$ and $\mathrm{Ni}$.

The Pearson correlation matrices using correlation coefficient ( $r$ ) for the fennel fruit and soil samples of the four sits are shown in Table 12. There is poor relation for $\mathrm{Mg}, \mathrm{Cu}, \mathrm{Cr}$, and $\mathrm{Co}$ in Addis Ababa site, $\mathrm{Ca}, \mathrm{Fe}, \mathrm{Co}$ and $\mathrm{Ni}$ in Bichena site and $\mathrm{Ni}$ and $\mathrm{Cd}$ in Debre Markos site between elements in the fennel fruit and soil. There is no relation between $\mathrm{Mg}$ in the soil and fennel fruit in Bichena site which might imply different sources. The rest elements have good relation (at least greater than \pm 0.5 ) between elements in the fennel fruit and soil.

\section{Conclusion}

In this study fennel fruit and the soil in which the plant was grown was analyzed for major and trace elements (Ca, Mg, Fe, Mn, $\mathrm{Cu}, \mathrm{Cr}, \mathrm{Co}, \mathrm{Zn}, \mathrm{Ni}, \mathrm{Cd}$ and $\mathrm{Pb}$ ). The fennel fruit was found to have higher concentration of $\mathrm{Ca}$, moderate concentration of $\mathrm{Mg}$ and $\mathrm{Fe}$, and lower but considerable concentration of $\mathrm{Cr}, \mathrm{Cu}, \mathrm{Co}, \mathrm{Mn}$ and $\mathrm{Zn}$; relatively low concentration of $\mathrm{Ni}$ and very low concentration of $\mathrm{Cd}$. The soil samples contain the highest concentration of Fe followed by $\mathrm{Mg}, \mathrm{Ca} \mathrm{Mn}, \mathrm{Co}, \mathrm{Cr}, \mathrm{Zn}$,

Table 12 Correlation of elements in the fennel fruit and soil samples in the four sits $(n=12)$

\begin{tabular}{|c|c|c|c|c|c|c|c|c|c|c|}
\hline Site/Elements/ & $\mathrm{Ca}$ & $\mathrm{Mg}$ & $\mathrm{Fe}$ & $\mathrm{Mn}$ & $\mathrm{Cu}$ & $\mathrm{Cr}$ & Co & $\mathrm{Zn}$ & $\mathrm{Ni}$ & $\mathrm{Cd}$ \\
\hline$\overline{\mathrm{AA}}$ & -0.842 & $0.425^{\bullet}$ & -0.663 & $0.985^{\boldsymbol{\Lambda}}$ & -0.290 & $0.464^{\bullet}$ & $0.300^{\bullet}$ & -0.993 & $0.683^{\boldsymbol{\Lambda}}$ & $0.500^{\boldsymbol{\Lambda}}$ \\
\hline B & -0.395 & $0.000^{*}$ & -0.092 & $0.947^{\wedge}$ & $0.615^{\boldsymbol{\Lambda}}$ & $0.957^{\wedge}$ & -0.366 & $0.704^{\wedge}$ & -0.211 & -0.500 \\
\hline DM & -0.613 & -0.707 & $0.979^{\wedge}$ & $0.756^{\boldsymbol{\Lambda}}$ & $0.936^{\boldsymbol{\Lambda}}$ & -0.699 & $0.977^{\wedge}$ & -0.998 & $0.219^{\bullet}$ & -0.013 \\
\hline FS & -0.721 & -0.689 & $0.569^{\wedge}$ & -0.966 & -0.693 & -0.950 & -0.500 & $0.862^{\Perp}$ & -0.984 & -0.619 \\
\hline
\end{tabular}

$\mathrm{AA}=$ Addis Ababa, $\mathrm{B}=$ Bichena, $\mathrm{DD}=$ Debre Markos, $\mathrm{FS}=$ Finote Selam.

Bold font indicates poor relation $(r>-0.500)$.

The * indicate no relation.

The ${ }^{\bullet}$ indicate poor positive relation $(r<0.500)$.

The ${ }^{\wedge}$ indicate strong positive relation $(r>0.500)$. 
$\mathrm{Ni}$, and $\mathrm{Cu}$. From the trace elements $\mathrm{Cu}$ showed higher accumulation factor. The concentration of $\mathrm{Cd}$ was higher in the soil than in the fennel fruit. Concentration of $\mathrm{Pb}$ in both the soil and the fennel fruit was below the method detection limit. For all the elements higher or comparable concentration were found in the soil and the fennel fruit except $\mathrm{Ca}$ in all the sites and $\mathrm{Cu}$ in Addis Ababa and Bichena sites.

The Ethiopian fennel fruit contain higher amount of $\mathrm{Ca}$, and considerable amount of other micronutrients. It contains only trace level of $\mathrm{Cd}$ and $\mathrm{Pb}$ was not detected which showed that it is safe for human consumption in daily life. These results may also indicate that fennel plant has lesser tendency to accumulate toxic elements in the fruit.

\section{Competing interests}

The authors declare that they have no competing interests.

\section{Authors' contributions}

FDE contributed to the sampling, analysis, and design of the study. FDE and BSC contributed to the interpretation of data and drafting the manuscript. BSC contributed to critical revision of the paper. All authors have read the manuscript and gave their final approval for this version of the manuscript to be published.

\section{Acknowledgements}

The authors express their gratitude to the Department of Chemistry, Addis Ababa University, Ethiopia, for providing the laboratory facilities. FDE is thankful to the Wolayta Sodo University, Wolayta Sodo, Ethiopia, for sponsoring his study.

\section{Funding}

This work was funded by Research and Graduate Programs of Addis Ababa University, Ethiopia.

Research and Graduate Programs of Addis Ababa University, Ethiopia had no role in the design, data collection, analysis or publication of the manuscript.

\section{Author details}

'Department of Chemistry, College of Natural Sciences, Addis Ababa University, P.O. Box 1176, Addis Ababa, Ethiopia. ${ }^{2}$ Department of Chemistry, Faculty of Natural and Computational Sciences, Wolayta Sodo University, P.O. Box: 138, Wolayta Sodo, Ethiopia.

Received: 19 August 2014 Accepted: 16 December 2014 Published: 3 January 2015

\section{References}

Başgel S, Erdemoğlu SB (2006) Determination of mineral and trace elements in some medicinal herbs and their infusions consumed in Turkey. Sci Total Environ 359:82-89

Cetin B, Ozer H, Cakir A, Polat T, Dursun A, Mete E, Ozturk E, Ekinci M (2010) Antimicrobial activities of essential oil and hexane extract of florence fennel [Foeniculum vulgare var. azoricum (Mill.) Thell.] against food borne microorganisms. J Med Food 13:196-204

Chéry CC, Herremans S, Lierde V, Vanhaecke F, Freitas MC, Jasekera R (2008) Ultra-micro trace element contents in spices from Sri Lanka. J Radioanal Nucl Chem 276:143-147

Chowdhary F, Bukhsh A, Chaman S, Naeem M (2014) Detection and measurement of zinc concentrations in selected indigenous medicinal plants of Pakistan. Adv Pharm Ethnomed 2:10-13

Dadalioglu I, Evrendilek GA (2004) Chemical compositions and antibacterial effects of essential oils of Turkish oregano (Origanum minutiflorum), bay laurel (Laurus nobilis), Spanish lavender (Lavandula stoechas L.), and fennel (Foeniculum vulgare) on common foodborne pathogens. J Agric Food Chem $52: 8255-8260$
Demirel S, Tuzen M, Saracoglu S, Soylak M (2008) Evaluation of various digestion procedures for trace element contents of some food materials. J Hazard Mater 152:1020-26

Desideri D, Meli MA, Roselli C, Feduzi L (2011) Determination of essential and non-essential elements in herbal tea and camomile by polarised $X$-rays fluorescence spectrometer (EDPXRF). J Radioanal Nucl Chem 290:391-396

Diao W-R, Hu Q-P, Zhang H, Xu J-G (2014) Chemical composition, antibacterial activity and mechanism of action of essential oil from seeds of fennel (Foeniculum vulgare Mill.). Food Control 35:109-116

Divrikli U, Horzum N, Soylak M, Elci L (2006) Trace heavy metal contents of some spices and herbal plants from western Anatolia, Turkey. Int J Food Sci Technol 41:712-16

El-Motaium RA, El-Seoud MAA (2007) Irradiated sewage sludge for production of fennel plants in sandy soil. Nutr Cycl Agroecosyst 78:133-142

FAO/WHO (2001) Human Vitamin and Mineral Requirements, report of a joint $\mathrm{FAO} / \mathrm{WHO}$ expert consultation

Faudale M, Viladomat F, Bastida J, Poli F, Codina C (2008) Antioxidant activity and phenolic composition of wild, edible, and medicinal fennel from different Mediterranean countries. J Agric Food Chem 56:1912-1920

Getahun A (1976) Some common medicinal and poisonous plants used in Ethiopian folk medicine. Addis Ababa University press, Addis Ababa, Ethiopia

He W, Huang B (2011) A review of chemistry and bioactivities of a medicinal spice: Foeniculum vulgare. J Med Plant Res 5:3595-3600

Javidnia K, Dastgheib L, Mohammadi Samani S, Nasiri A (2003) Antihirsutism activity of fennel (fruits of Foeniculum vulgare) extract - a double-blind placebo controlled study. Phytomedicine 10:455-458

Khattak MI, Khattak MI (2011) Study of heacy trave metals in some medicinal-herbal plants of Pakistan. Pakistan J Bot 43:2003-2009

Kim SI, Chang KS, Yang YC, Kim BS, Ahn YJ (2004) Repellency of aerosol and cream products containing fennel oil to mosquitoes under laboratory and field conditions. Pest Manag Sci 60:1125-1130

Kitata RB, Chandravanshi BS (2012) Concentration levels of major and trace metals in onion (Allium cepa L.) and irrigation water around Meki Town and Lake Ziway, Ethiopia. Bull Chem Soc Ethiop 26:27-42

Kumar A, Nair AGC, Reddy AVR, Garg AN (2005) Analysis of essential elements in Pragya-peya a herbal drink and its constituents by neutron activation. J Pharm Biomed Anal 37:631-638

Mallinckrodt MG-v, Meissne D (1994) General aspects of the role of metals in clinical chemistry. In: Seiler HG, Sigel A, Sige H (eds) Handbook on Metals in Clinical and Analytical Chemistry. Marcel Dekker, New York, pp 4-27

Mohamad RH, El-Bastawesy AM, Abdel-Monem MG, Noor AM, Al-Mehdar HA, Sharawy SM, El-Merzabani MM (2011) Antioxidant and anticarcinogenic effects of methanolic extract and volatile oil of fennel seeds (Foeniculum vulgare). J Med Food 14:986-1001

O'Dell BL, Sunde RA (1997) Handbook of Nutritionally Essential Mineral Elements Clinical Nutrition in Health and Disease. CRC Press, New York

Oktay M, Gülçin I, Küfrevioğlu Öi (2003) Determination of in vitro antioxidant activity of fennel (Foeniculum vulgare) seed extracts. LWT - Food Sci Technol 36:263-271

Ozcan MM, Akbulut M (2007) Estimation of minerals, nitrate and nitrite contents of medicinal and aromatic plants used as spices, condiments and herbal tea. Food Chem 106:852-858

Ozcan MM, Unver A, Ucar T, Arslan D (2008) Mineral content of some herbs and herbal teas by infusion and decoction. Food Chem 106:1120-1127

Parthasarathy VA, Chempakam B, Zachariah TJ (2008) Chemistry of Spices. CAB International, UK

Qiu J, Li H, Su H, Dong J, Luo M, Wang J, Leng B, Deng Y, Liu J, Deng X (2012) Chemical composition of fennel essential oil and its impact on Staphylococcus aureus exotoxin production. World J Microbiol Biotechnol 28:1399-1405

Rahimi R, Ardekani M (2013) Medicinal properties of Foeniculum vulgare Mill. in traditional Iranian medicine and modern phytotherapy. Chin J Integr Med 19:73-79

Rasul A, Akhtar N, Khan BA, Mahmood T, Uz Zaman S, Khan HM (2012) Formulation development of a cream containing fennel extract: in vivo evaluation for anti-aging effects. Pharmazie 67:54-58

Rather MA, Dar BA, Sofi SN, Bhat BA, Qurishi MA (2012) Foeniculum vulgare: A comprehensive review of its traditional use, phytochemistry, pharmacology, and safety. Arabian J Chem http://dx.doi.org/10.1016/j.arabjc.2012.04.011

Renna M, Gonnella M (2012) The use of the sea fennel as a new spice-colorant in culinary preparations. Int J Gastronomy Food Sci 1:111-115 
Sembratowicz I, Rusinek-prystupa E (2014) Effects of brewing time on the content of minerals in infusion of medicinal herbs. Polish J Environ Stud 23:177-186

Senatore F, Oliviero F, Scandolera E, Taglialatela-Scafati O, Roscigno G, Zaccardelli M, De Falco E (2013) Chemical composition, antimicrobial and antioxidant activities of anethole-rich oil from leaves of selected varieties of fennel [Foeniculum vulgare Mill. ssp. vulgare var. azoricum (Mill.) Thell]. Fitoterapia 90:214-219

Shahat AA, Ibrahim AY, Hendawy SF, Omer EA, Hammouda FM, Abdel-Rahman FH, Saleh MA (2011) Chemical composition, antimicrobial and antioxidant activities of essential oils from organically cultivated fennel cultivars. Molecules 16:1366-1377

Shirahatt RV, Ankola AV, Nagesh L (2010) Effect of fennel seeds on dental plaque and salivary pH - a clinical study. J Oral Health Community Dent 4:38-41

Singh V, Garg AN (2006) Availability of essential trace elements in Indian cereals, vegetables and spices using INAA and the contribution of spices to daily dietary intake. Food Chem 94:81-89

Szymczycha-Madeja A, Welna M, Pohl P (2012) Elemental analysis of teas and their infusions by spectrometric methods. Trends Anal Chem 35:165-181

Zengin M, Özcan MM, Çetin Ü, Gezgin S (2008) Mineral contents of some aromatic plants, their growth soils and infusions. J Sci Food Agric 88:581-589

Zuberi MI, Kebede B, Gosaye T, Belachew O (2014) Species of herbal spices grown in the poor farmers' home gardens of West Shoa, Highlands of Ethiopia: an ethnobotanical account. J Biodivers Environ Sci 4:164-185

doi:10.1186/2193-1801-4-5

Cite this article as: Endalamaw and Chandravanshi: Levels of major and trace elements in fennel (Foeniculum vulgari Mill.) fruits cultivated in Ethiopia. SpringerPlus 2015 4:5.

\section{Submit your manuscript to a SpringerOpen ${ }^{\circ}$ journal and benefit from:}

- Convenient online submission

- Rigorous peer review

- Immediate publication on acceptance

- Open access: articles freely available online

- High visibility within the field

- Retaining the copyright to your article

Submit your next manuscript at $\gg$ springeropen.com 